\title{
Fenomen reality televizije: od zabave do edukacije
}

Prethodno priopćenje _ DOI 10.22522/cmr20190150__ primljeno 16. siječnja 2018.

UDK: $654.172: 791.43(0 \overline{5})$

379.82-027:37-027

\section{Nensi Blažević}

Filozofski fakultet (doktorand), Zagreb, Hrvatska.

E-adresa: nensi.blazevic@gmail.com

\section{Jana Bušić}

Hrvatska.

E-adresa: janabusic@gmail.com

\section{Stana Odak Krasić}

Veleučilište VERN', Zagreb, Hrvatska.

E-adresa: stana.odak.krasic@vern.hr

\section{Sažetak}

Reality televizija postala je društveni fenomen. Predmet je brojnih rasprava i analiza jer je jedan od najgledanijih televizijskih sadržaja, a izaziva oprečna mišljenja: neki je pasionirano gledaju i u njoj pronalaze zabavu te bijeg od stvarnosti, a drugi pak zaziru od same pomisli na takav sadržaj. Reality programi mogu sadržavati neprimjerene sadržaje za sudionike i gledatelje svih uzrasta, ali mogu biti i edukativni. Uz vrlo popularne reality emisije poput Skrivene kamere i Big Brothera, manje su poznate one emisije koje su svojedobno služile kao socijalni eksperimenti radi znanstvenih istraživanja, kao što je promatranje ponašanja ljudi u zatvorenim zajednicama. lako su istovremeno šokantni većini ljudi, takvi realityji sadrže i edukativne elemente. U ovome se radu metodom ankete istražuje mogu li reality programi, osim što su zabavni, biti i edukativni. Također, analizira se zašto ljudi gledaju takve sadržaje i identificiraju se s njima.

Ključne riječi: mediji, televizija, reality programi, zabavni i edukativni sadržaji 


\section{Uvod}

Gledanje televizije često je bijeg u drugi svijet, odmor od posla, odmak od problema, način opuštanja i razbibrige u slobodno vrijeme, ali i sredstvo informiranja i obrazovanja. Temeljne funkcije televizije i jesu informiranje, obrazovanje i zabava. Dojam je da današnji televizijski program mora biti što spektakularniji jer se, osobito novim generacijama koje u svakom trenutku istovremeno koriste nekoliko različitih platformi, osjetila treba „okupirati“ i privući na više razina. Upravo zbog toga raste i popularnost i količina reality programa.

Danas se reality sve više koristi i u svrhu socioloških istraživanja ponašanja ljudi u različitim situacijama, kao primjerice simulirana Ekspedicija na Mars u kojoj se željelo vidjeti kako bi se mala skupina ljudi snašla na Marsu u slučaju da Zemlja više nije naseljiva. Velika gledanost uzrokovala je i pojavu velikog broja šokantnih emisija. U nekima je, primjerice, jedini cilj natjecanje u zavođenju pri čemu se muškarci i žene ismijavaju i ponižavaju poput reality emisije The Bachelor. Takvo pretvaranje ljudi u vijesti i pijune, koje neki uživaju gledati, nailazi i na veliki otpor u društvu. Protivnici realityja smatraju da on zaglupljuje, dok s druge strane zagovaratelji smatraju da služi samo kao dobra zabava. Protivnike su takvi sadržaji, primjerice u Srbiji, potaknuli i na potpisivanje peticije za ukidanje takvog programa.

Glavni je cilj ovoga rada bio istražiti mogu li reality programi, osim što su zabavni, imati i edukativne karakteristike. Također, željelo se istražiti zašto publika gleda takve sadržaje, identificira li se s njima i razumije li njihovu sociološku vrijednost.

\section{Pojam, počeci i razvoj reality televizije}

Prema definiciji realityja u Oxfordskom internetskom rječniku (2016), glavni je cilj takvog programa zabaviti gledatelja, a ne ga educirati: „Reality TV - televizijski programi u kojima su obični ljudi izloženi stalnom snimanju, osmišljeni da budu zabavni, a ne edukativni.“U Leksikonu radija i televizije (2016) pojam reality televizija opisan je kao žanr televizijskog programa koji se temelji na formuli sudjelovanja običnih ljudi, izabranih kako bi odražavali različita stajališta i način života. Žanr takve televizije nastao je kombiniranjem žanra skrivene kamere (npr. show Candid camera) sa žanrom natjecateljskoga showa, a uključuje i ispovjednu vrstu talk showa koji težište stavlja na emocionalno razotkrivanje intime običnih ljudi. U Hrvatskoj je najpoznatija inačica reality televizije emisija Big Brother, 
a obuhvaća i različite druge programske formate koji u tradicionalne žanrove ubacuju element „stvarnosti“, kao što su dokumentarna drama, natjecanje talenata - amatera i dokumentarni kvizovi. Uporabom novih komunikacijskih platformi (SMS, Whatsapp, e-pošta), a posebno interneta, na kojima se u stvarnom vremenu emitira 24 sata na dan, Big Brother kao glavni primjer reality televizije postao je novi oblik medijskoga programa koji nadrasta TV emitiranje.

Filmologinja Ivana Kronja u svome radu „Čovjek tranzicije u mas-medijskom društvu“ objašnjava što je reality: „To je oblik dugoročnog, serijskog igrano-dokumentarnog programa u kome su ljudi, do tada anonimni ili pak slavni, stavljeni na egzotične lokacije ili u neuobičajene situacije, da bi se njihovo ponašanje 'promatralo' kamerama i potom oblikovalo u postprodukciji (montaži) “ (Kronja, 2008, str. 104). Budući da se reality s godinama razvijao, a ponajviše zahvaljujući utjecaju tehnologije, počeli su se oblikovati i razni podžanrovi reality formata. Tri najgledanija realityja u Hrvatskoj u listopadu 2015., prema istraživanju gledanosti televizijskih programa Agencije za elektroničke medije (2015), bili su Farma, Tvoje lice zvuči poznato i Big Brother.

"U listopadu 2015. godine, nakon Dnevnika Nove TV i nogometa, odnosno kvalifikacija za Europsko prvenstvo, najgledanije emisije su Tvoje lice zvuči poznato i Farma. Usporedbe radi, politički talk-show Nedjeljom $u 2$ nalazi se na desetom mjestu. Ciljna skupina od 18 do 49 godina pokazuje samo malo drugačije podatke. Emisija Tvoje lice zvuči poznato dospjela je na prvo mjesto, slijede nogomet i Dnevnik Nove TV na drugom i trećem mjestu pa Big Brother iz kuće, Big Brother dnevna emisija, Farma, nogomet, Zvjezdice, Big Brother i opet nogomet. Dakle, od deset najgledanijih programa šest čine reality showovi, tri nogometne emisije i jedna informativna. Bitno je spomenuti i da se reality showovi ne prikazuju tijekom cijele godine pa se ovakvi podaci ni ne ponavljaju svakog mjeseca, dakle, nema kontinuiteta.“ (Agencija za elektroničke medije, 2015)

Iako vrlo popularne, te su emisije i vrlo različite, a gledanjem se može uočiti razlikovanje prema temi, vrsti natjecanja, formatu i ciljanoj publici, stoga dobro ilustriraju koliko je raznolik žanr realityja.

\section{Počeci reality televizije i njịhov razvoj}

Prva reality emisija Candid Microphone počela se emitirati na radiju 1947., da bi se samo godinu dana kasnije počela prikazivati na televiziji (Sanderson, 1999). Skrivena kamera 
(Candid Camera) Allana Funta 1948. prva je uz pomoć skrivenih kamera pokazala kako različiti ljudi reagiraju na razne smicalice kojima su izloženi. „Neki od njegovih gegova korišteni su sa studentima psihologije i sociologije: primjerice, vrata na kojima piše 'Molimo koristite druga vrata', a na drugim vratima 'Zabranjen ulaz' ili trik s dizalom gdje bi članovi Funtova tima ušli u dizalo i okrenuli se prema zadnjem dijelu, a ne prednjem. Uskoro su svi ljudi koji bi ušli u dizalo gledali na krivu stranu. Funt je rekao kako je to dobra ilustracija psihologije grupnog pritiska." (Sanderson, 1999) David Reisman, sociolog s Harvarda, nazvao je Funta drugim najdomišljatijim sociologom u Americi (prema Sanderson, 1999). Potom se 1965. pojavila američka televizijska serija The American Sportsman na ABC-ju koja je u 60 minuta prikazivala najzanimljivije dijelove programa s natjecateljima i slavnim osobama koje se natječu u nizu sportskih aktivnosti kao što su lov i ribolov, kajak, penjanje i slično (Hobbyfan, 2014).

Dvadeset godina kasnije Al Giddings, snimatelj podvodnih motiva, udružio se s tadašnjom Miss Amerike Shawn Weatherly u NBC-jevom serijalu Ocean Quest koji je prikazivao njene podvodne avanture na različitim egzotičnim lokacijama, a Weatherly je nominirana za nagradu Emmy za izvanredna postignuća u informativnom programu (EmmyAwards, 2016).

TV serijal Broj 28 počeo se prikazivati na nizozemskoj televiziji 1991. i bio je začetnik koncepta u kojemu se stranci stavljaju u istu okolinu na duže vrijeme, pri čemu se, naravno, snima sva „drama“ koja se događa (Reality Television Show, 2017). Broj 28 u svom formatu koristi mnoge tehnike koje će kasnije postati standard u reality televiziji, uključujući ispovjedaonicu i glazbu koja prati radnju (Burns, 2009, str. 33). Godinu dana kasnije, 1992. godine, MTV je počeo koristiti sličan koncept i prikazivati ga kao serijal The Real World koji se zadržao na televiziji sve do 2013. godine (Reality Television Show, 2017).

Charlie Parsons je 1994. kreirao reality emisiju Expedition Robinson u kojoj su natjecatelji stavljeni u situacije $u$ kojima moraju preživjeti samo na temelju vlastite snalažljivosti, a sustav međusobnog glasanja eliminira po jednu osobu dok ne ostane samo jedan pobjednik (IMDb, 1990). Emisija je prvobitno bila namijenjena britanskom tržištu, a prikazana je tek 1997. na švedskoj televiziji. Američka verzija Survivor počela se prikazivati 2000. godine (IMDb, 1990).

Na CBS-u se 2000. pojavljuje Big Brother i tamo se prikazuje do danas, dok se u Hrvatskoj počeo prikazivati na RTL televiziji od 2004. godine (Filipović, 2014). Tada je emisija postigla odlične reakcije publike i postala jedan od prvih ogromnih uspjeha, pa i obilježja, 
RTL televizije. U razdoblju od 2000. do 2007. reality žanr doživio je najveći porast broja novih emisija. Pojavio se Američki idol, X-factor, Top Model, Masterchef, Ples sa zvijezdama i kvizovi Milijunaš te Najslabija karika. Godine 2004. pojavio se i Pripravnik Donalda Trumpa u kojemu se 12 poduzetnika kroz niz zadataka borilo za nagradu od 25 tisuća dolara i prestižni posao kod samog Trumpa. Godine 2010. veliki uspjeh u Hrvatskoj i svijetu postiže The Voice $\mathrm{u}$ kojemu se glazbeni talenti natječu za nagradu najboljeg amaterskog pjevača.

The Academy of Television Arts and Sciences 2001. dodala je reality žanr u Emmy nagrade, priznajući reality program izvan kategorije fikcije. Od prvotnih osam kategorija 2001. godine, danas se razlikuju 22 različite kategorije za reality i ne-fikciju (EmmyAwards, 2016).

\section{Stanfordski fenomen}

Reality program vrlo se brzo razvijao zahvaljujući zabavnom učinku koji ima na gledatelje, no sami počeci ovakvog programa započinju nakon Drugog svjetskog rata testiranjem $\mathrm{u}$ socijalnoj psihologiji, iz kojih će kasnije proizaći razne varijacije u sklopu reality emisija (Plečko, 2016). Jedan od takvih je tzv. stanfordski fenomen. „Što se dogodi kad dobre ljude stavite na zlo mjesto? Hoće li humanost pobijediti zlo ili će zlo trijumfirati?“ (Zimbardo, 2016). To su neka od pitanja koja su znanstvenici istraživali u ovoj dramatičnoj simulaciji zatvorskog života. Profesor psihologije na Stanfordu Philip G. Zimbardo proveo je 1971. eksperiment, a rezultati su iznenadili i njega samog. „Moglo bi vas iznenaditi kako smo testirali ova pitanja i što smo otkrili. Naša planirana dvotjedna istraga o psihologiji zatvorskog života morala se prekinuti nakon samo šest dana zbog posljedica koje je ostavljala na sudionike. Nakon samo nekoliko dana, naši su se čuvari počeli ponašati sadistički, a zatvorenici depresivno te su pokazivali znakove velike izloženosti stresu.“ (Zimbardo, 2016) Nakon opsežnih testiranja za eksperiment su odabrana 24 studenta od kojih je nasumično odabrano 9 čuvara i 9 zatvorenika, dok je ostatak bio u pripravnosti, ako ih zatrebaju (Zimbardo, 2016). Devetoricu „zatvorenika“ u ljeto 1971. privela je policija u okolici Palo Alta (SAD) ispred njihovih kuća, dok su susjedi cijelo vrijeme promatrali što se događa (Zimbardo, 2016). Kada su stigli u stanfordski okružni zatvor, skinuti su do gola,

pretraženi, uzeti su im otisci, zaprašeni su dezinfekcijskim praškom i hladnom vodom te su odjeveni, ne u zatvorske uniforme, nego dugačke haljine i kape napravljene od ženskih 
najlonskih čarapa. Posebno opremljen zatvor sadržavao je tehnologiju za tajno snimanje i prisluškivanje razgovora zatvorenika, kao i samicu u koju su zatvorenici poslani ako se ne bi ponašali onako kako se od njih očekuje. Cilj je bio poniziti i osramotiti zatvorenike. Iako ovo nije bio pravi zatvor, Zimbardo (2016) je pokušao što više približiti eksperiment pravim zatvorskim uvjetima kako bi vidio utjecaj institucije na sve koji se nalaze unutar zatvorskih zidova. Čuvari su dobili uniforme i reflektivne naočale kako bi im bilo teže vidjeti oči i čitati emocije s lica. Međutim, nisu dobili nikakve upute kako se ponašati ili biti čuvari i imali su potpunu slobodu ponašati se kako žele. Jedino upozorenje koje su dobili bilo je o potencijalnoj štetnosti i opasnostima ovoga posla.

Dva su razloga zbog kojih je eksperiment prekinut nakon šest dana. Prvo, čuvari su počeli previše uživati u kažnjavanju zatvorenika. Maltretirali su ih usred noći kada su mislili da ih nitko ne gleda, a zatvorenici su počeli vjerovati kako je ovo pravi zatvor, da nikada neće izaći van i kao posljedica svega to se odrazilo i na njihovo psihičko stanje. Drugi je razlog bio upitna moralnost cijelog eksperimenta. Cristina Maslach, doktorandica sa Stanforda, bila je zgrožena cijelim eksperimentom i jedina je (od više od 50 ljudi koji su došli u zatvor) rekla da nešto nije u redu s cijelom situacijom i eksperimentom.

Nemoralnost i neetičnost eksperimenta nisu u potpunosti prepoznali niti na BBCju kad su 2002. pokušali napraviti reality emisiju The Experiment po uzoru na Stanford Prison Experiment (Stannard, 2002). Program je trebao imati dvije grupe: zatvorenike i stražare koji bi se nalazili u lažnom zatvoru i u kojemu bi u deset dana snimali sve što se događa. „Vjerujemo da je naše istraživanje bitno za trenutačne probleme u društvu i da će produbiti debatu o socijalnom ponašanju daleko više od uvida stanfordskog zatvorskog slučaja, ali bez kompromitiranja etičkih standarda“, rekao je Alexander Haslam, jedan od dvojice psihologa koji su radili na emisiji (Stannard, 2002). BBC je pitao i Zimbarda da sudjeluje u izradi showa, no on ih je odbio. Iako je njegova studija postala orijentir $\mathrm{u}$ socijalnoj psihologiji, danas se također smatra i prijepornom na više razina. Zimbardov je eksperiment pionirski u shvaćanju toga kako društvene okolnosti mogu nadići druge faktore, kao npr. stalež, inteligenciju, religiju i osobnost. „U nekom smislu, zatvorska studija bila je jedan od prvih primjera reality televizije jer smo snimali cijelu proceduru“ (Stannard, 2002).

Priče o socijalnim eksperimentima u obliku realityja nisu stale na tome. Godine 2014. osmišljen je reality u kojemu se natjecatelji pripremaju za odlazak u svemir, odnosno kolonizaciju Marsa (Andreeva, 2014). Ideja je to nizozemskog milijardera Basa Lansdorpa, 
koji je htio okupiti ljude i trenirati ih da jednog dana budu prva kolonizacija ljudi na Marsu. Plan je da se svake dvije godine, počevši s 2024., na Mars pošalje tim od četiri osobe koje bi započele kolonizaciju. U nekoliko mjeseci za misiju se prijavilo 300 tisuća ljudi, od kojih će samo nekolicina proći osmogodišnji trening i otići na Mars. Svaki od njih zna da je to put s kojega se možda neće vratiti (Andreeva, 2014).

\section{Protivnici realityja il peticije za ulkidanje}

Druga strana priče pokazuje da postoje mnogi pojedinci u društvu koji žele stati na kraj ovakvom sadržaju. Agencija za elektroničke medije (2016) u svojim Preporukama, namijenjenima medijskim djelatnicima, roditeljima i nastavnicima, navodi, među ostalim, i smjernice za klasifikaciju potencijalno štetnih audiovizualnih sadržaja za djecu i mlade. Reality programi mogu sadržavati štetne sadržaje za djecu i mlade, za one koji ih samo gledaju te za one koji u njima sudjeluju. U njima se znaju podržavati rodni stereotipi, naglašavati seksualnost i tjelesni izgled, a ponekad se potiče i veliča nasilničko ponašanje i izazivanje sukoba među ljudima. Neka istraživanja pokazuju da djeca koja učestalo gledaju reality programe u značajno većoj mjeri vjeruju kako su za sreću potrebni bogatstvo, popularnost i ljepota (Medijskapismenost.hr, 2017).

U susjednoj Srbiji udruga studenata „Sistem vrednosti“ na Pravnom fakultetu u Beogradu pokrenula je akciju „Hoćemo kulturu, a ne realitije“ i odigrala je ključnu ulogu u povećanju glasova u peticiji za ukidanje realityja s televizije s nacionalnom koncesijom $\mathrm{u}$ udarnom terminu. Nakon što su se mediji uključili u akciju, peticiju je potpisalo više od 100 tisuća ljudi u Srbiji (Peticije24.com, 2016). Njome se, međutim, nije ništa postiglo. Glavni argumenti za nastavak emitiranja bili su da se vlasniku privatne televizije ne može nametati što će prikazivati i onaj „banalni“ - da postoji daljinski upravljač za prebacivanje programa.

RTL Hrvatska također je dobila pritužbe za svoj sadržaj u sedmoj sezoni Big Brothera 2015. godine (B. La, 2015). Pravobraniteljica za djecu Ivana Milas Klarić i Agencija za elektroničke medije reagirali su na seksualne scene koje su se prikazivale u neprimjerenom terminu, prije 22 sata:

„Stajalište je pravobraniteljice za djecu da sadržaji emisije Big Brother RTL televizije nisu primjereni djeci, odnosno da sadržavaju prizore za koje je vjerojatno da bi mogli 
narušiti fizički, mentalni ili moralni razvoj maloljetnika. I u prijašnjim sezonama emitiranja te emisije preporučili smo da se takvi sadržaji ne bi trebali prikazivati prije 22 sata što podrazumijeva i preporuku da se takvi sadržaji ne repriziraju tijekom dana, kao i to da bi njihove najave svakako trebale biti bez prizora koji mogu štetno djelovati na djecu. Štetno djelovanje sadržaja ovakvih emisija pojačano je upravo time što djeca mlađe dobi ne mogu ispravno procijeniti kontekst u kojemu se odvijaju događaji u kući Velikog brata, gdje se namjerno najčešće u prvi plan ističu bizarna i negativna ponašanja te vulgarnosti. Od roditelja se očekuje da prate i usmjeravaju navike djece i u gledanju TV programa te da utječu na njihovu medijsku pismenost. No, ako se sadržaji poput Big Brothera prikazuju tijekom dana, kad su djeca često sama kod kuće, roditeljima je znatno otežano odgajati svoju djecu i utjecati na njihov izbor programa. Nadzor nad provedbom Zakona o elektroničkim medijima i nadležnost za odlučivanje o štetnosti sadržaja te konkretnim mjerama i sankcijama ima Vijeće za elektroničke medije koje o tome samostalno donosi odluku pa se nadamo da će reagirati na odgovarajući način.“ (B. La, 2015).

RTL je nakon tih pritužbi reagirao tako da je prikazivanje Big Brothera pomaknuo u kasniji noćni termin, dok reprize tijekom dana nije bilo. U priopćenju RTL-a, koje je potpisala direktorica komunikacija Nataša Roksandić, istaknuli su da su „poduzeli (...) potrebne mjere kako bismo dodatno prilagodili sadržaj emisije Big Brother terminu prikazivanja od 21.00 sata, a sve sukladno odredbama Zakona o elektroničkim medijima. Stoga sadržaj emisije Big Brother koji se prikazuje u terminu od 22.45 nosi oznaku ' 15 ' te se ne reprizira u popodnevnom terminu.“ (B. La, 2015) Uz to, Vijeće za elektroničke medije donijelo je odluku o izdavanju prekršajnog naloga RTL-u kao pravnoj osobi u iznosu od 100 tisuća kuna, a odgovorne su osobe kažnjene s 10 tisuća kuna (B. La, 2015).

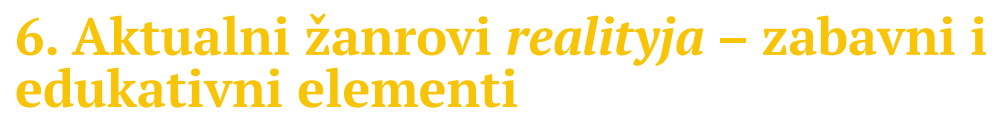

Reality program najčešće za cilj ima zabaviti gledatelje. No, s obzirom na rast gledanosti takvih emisija, postavlja se pitanje mogu li gledatelji i nešto naučiti u takvim formatima te na koji način. U radu će se na temelju odabranih reality emisija pokušati ukazati na raznolikost reality programa, odnosno na omjer zabavnih, edukativnih i informativnih sadržaja. Kroz analizu emisija Big Brother i Survivor, istražit će se omjer zabavnih i edukativnih elemenata u programu te poruke koje takvi programi prenose gledateljima. 
Navedene su emisije odabrane zbog svoje raznolikosti, odnosno zbog mogućnosti prikaza različitih elemenata unutar naizgled jednostranog programa. Big Brother je izabran kao program koji prikazuje ljude u izoliranoj kući i kojemu je primarni cilj zabava, dok je Survivor odabran jer kao i Big Brother prikazuje izoliranu skupinu ljudi, ali s drugačijim načinima zabavljanja gledatelja koji na svojim marginama može sadržavati i edukativne elemente.

\subsection{Big Brother}

Big Brother je emisija u kojoj dvadesetak ljudi živi u izoliranoj kući. Pritom se sve aktivnosti sudionika emisije snimaju 24 sata dnevno u razdoblju od gotovo tri mjeseca. Stanari se natječu putem tjednih zadataka za nagradni iznos kojim opskrbljuju domaćinstvo u kojemu žive. Postoje točno određena pravila kojih se stanari moraju pridržavati dok su u Big Brother kući. Ovo su neka od njih:

„Zabranjen je svaki kontakt s vanjskim svijetom, uključujući korištenje interneta, telefona, čitanja novina i razgovora bilo s kime osim s Velikim bratom. Nošenje mikrofona je obavezno za cijelo vrijeme boravka u kući. Ne smije se pričati o nominacijama s drugim stanarima ili utjecati na druge pri odluci za koga će se glasati. Javnost odlučuje tko će biti izbačen iz kuće. Ne smije se prijetiti ili fizički napadati bilo kojeg stanara u kući. Ne smije se pomicati namještaj niti bilo što drugo u kući. Obavezno je ustati iz kreveta kada god se čuje alarm." (Pravila Big Brothera, 2016)

Promatrajući količinu edukativnog u odnosu na zabavni sadržaj, primjetno je da je cilj programa dovođenje stanara u neugodne situacije, moguće sramoćenje i izazivanje smijeha kod gledatelja. Pritom je u emisiji prisutno više zabavnih, nego edukativnih sadržaja. U emisiji se prihvaća nemoral i odstupanje od etički ispravnih odluka radi zabave. Gledatelja se angažira tako da mora pratiti i glasati za izbacivanje, odnosno ostavljanje stanara $\mathrm{u}$ kući, a stanare se izolacijom i komforom potiče na ponašanje na granicama morala radi zabave i stjecanja slave.

\subsection{Survivor}

Survivor okuplja dvadesetak natjecatelja koji 39 dana zajedno preživljavaju na izoliranoj plaži, istovremeno se boreći jedan protiv drugog u nizu zadataka kako bi na kraju „preživio“ samo jedan. Nagrada od milijun dolara velika je motivacija da se netko izloži vremenskim uvjetima, a producenti programa trude se zabaviti gledatelje i prikazivanjem autentičnih 
sela, naroda i običaja zemalja u kojima se snima Survivor. Osim toga, gledatelj nema nikakvu odluku u krajnjem odabiru pobjednika - za razliku od Big Brothera - pa su natjecatelji oslobođeni brige kako izgledaju pred kamerama i ne teže slavi. Fokus je na nadmudrivanju, izdržljivosti i što duljem ostanku u igri (moto je igre „Outwit, outlast, outplay“).

Budući natjecatelji, i oni koji će to možda postati, moraju potpisati vrlo detaljan ugovor o tome što smiju i ne smiju prije i tijekom igre. Čitanjem ugovora može se primijetiti da su ograničenja puno veća u razdoblju dok igrači nisu u igri, dakle, prije i poslije same igre. Između ostalog, ugovor ih obvezuje na sljedeće:

„Živjet će 'primitivno', odnosno bez struje i pitke vode te će sami sagraditi svoju nastambu (jedna od dnevnih obaveza i poslova koje obavljaju); neće utjecati na ishod igre na lažan i nepošten način, odnosno, strogo je zabranjen dogovor o podjeli novčane nagrade s nekim od natjecatelja. Ako to netko i ponudi, odmah se mora obavijestiti producente emisije. Strogo je zabranjeno dijeliti nagradu s bilo kojim natjecateljem u bilo kojoj mjeri; pristaju da u razdoblju koje odredi CBS neće, pod svojim imenom ili nadimkom, objavljivati i komentirati igdje na internetu (internetske stranice, chat sobe, Myspace ...), bez obzira radi li se o Survivoru ili ne; natjecatelji pristaju na intervenciju liječnika te ako je potrebno i testiranje uz upozorenje na opasnosti koje pruža medicinska pomoć u bolnicama na zabačenim lokacijama, na kojima se možebitno snima emisija; neće oštećivati zaštićenu i rijetku floru i faunu prema dogovoru s producentima." (Realityblurred.com, 2017).

Iako je glavni cilj programa zabava, može se prepoznati i edukativni dio kroz upoznavanje kultura i mjesta u kojima se snima emisija, vještine preživljavanja u divljini i natjecanja te raznovrsnih divljih životinja koje se često mogu vidjeti u emisijama. Nadalje, iako zabava ostaje primarni cilj emisije, neki natjecatelji mogu biti primjer kako se uz snalažljivost i prilagodljivost situacijama koje su izvan „zone komfora“ može postići uspjeh. Isto tako, nepomaganje zajednici i konfliktnost nekih natjecatelja dovode do neuspjeha i izbacivanja iz igre.

Zanimljivo je da pretpostavka, koja je odredila i ime žanra, da gledatelji gledaju stvarni život, odnosno da se show odvija bez scenarija, zapravo iluzija jer su svi programi reality televizije napisani i režirani (a i naknadno montirani) te se u svakom slučaju može računati na to da se i eventualni edukativni dio lako može „odrezati“ prilikom montaže. 


\section{Ciljevi, hipoteze i metoda istraživanja}

Primarni cilj rada bio je istražiti prisutnost edukativnih elemenata reality emisija te utvrditi stavove ispitanika o tome mogu li nešto naučiti gledajući reality programe. Iako primarni cilj realityja nije edukacija, nego zabava gledatelja, online anketom se željelo ispitati prepoznaju li gledatelji edukativne sadržaje u takvim emisijama. Osim toga, željelo se istražiti i koliko su reality showovi gledani jer istraživanja gledanosti pokazuju da je reality program jedan od najgledanijih televizijskih sadržaja (Agencija za elektroničke medije, 2015). Na temelju navedenih ciljeva istraživanja, u radu su postavljene sljedeće hipoteze:

$H_{1}$ : Reality je gledan i popularan televizijski program.

$\boldsymbol{H}_{2}$ : Reality televizija ima i edukativne elemente.

S ciljem dokazivanja druge hipoteze, $\mathrm{u}$ radu je korištena metoda online ankete. „U širem smislu anketa je svako prikupljanje podataka uz pomoć postavljanja pitanja“ (Vujević, 2002, str. 124), a u užem smislu „anketa je pismeno prikupljanje podataka o stavovima i mišljenjima na reprezentativnom uzorku ispitanika uz pomoć upitnika“ (Vujević, 2002, str. 124). Miroslav Vujević također navodi kako anketa može služiti kao metoda otkrića, no najčešće se koristi kao metoda verifikacije, odnosno prikupljaju se podaci koji služe za provjeru određenih hipoteza (2002, str. 125). Anketa je, uostalom, „najčešće korištena tehnika prikupljanja podataka u društvenim znanostima čija je primjena toliko raširena da se smatra znanstvenom metodom“"(Tkalac Verčič i sur., 2010, str. 103).

U online anonimnoj anketi sudjelovalo je 167 ispitanika. U istraživanju su sudjelovali ispitanici između 15 i 55 godina, iako nije bilo dobnog ograničenja. Anketa je distribuirana putem poveznice na raznim tematskim forumima, društvenim mrežama i e-poštom. Pokrenuta je 26. listopada 2015. i zatvorena 8. srpnja 2016. S obzirom na mali broj ispitanika $\mathrm{u}$ anketi, nije bilo moguće dobiti reprezentativne rezultate, već je prikazan trend. 


\section{Rezultati istraživanja}

Istraživanjem je potvrđena hipoteza da gledatelji rado gledaju reality programe. Ispitanici prepoznaju i edukativne elemente takvih emisija. Može se reći kako je prva postavljena hipoteza u cijelosti potvrđena (vidi Grafikon 1), dok je druga tek djelomično potvrđena (vidi Grafikon 8 i 9).

Uzorak od ukupno 167 ljudi pokazuje da ljudi različitih godina i spola uživaju u gledanju reality programa te da je većina ispitanih gledala više od samo jednog reality programa (iako su tvrdili da ne gledaju takve sadržaje.

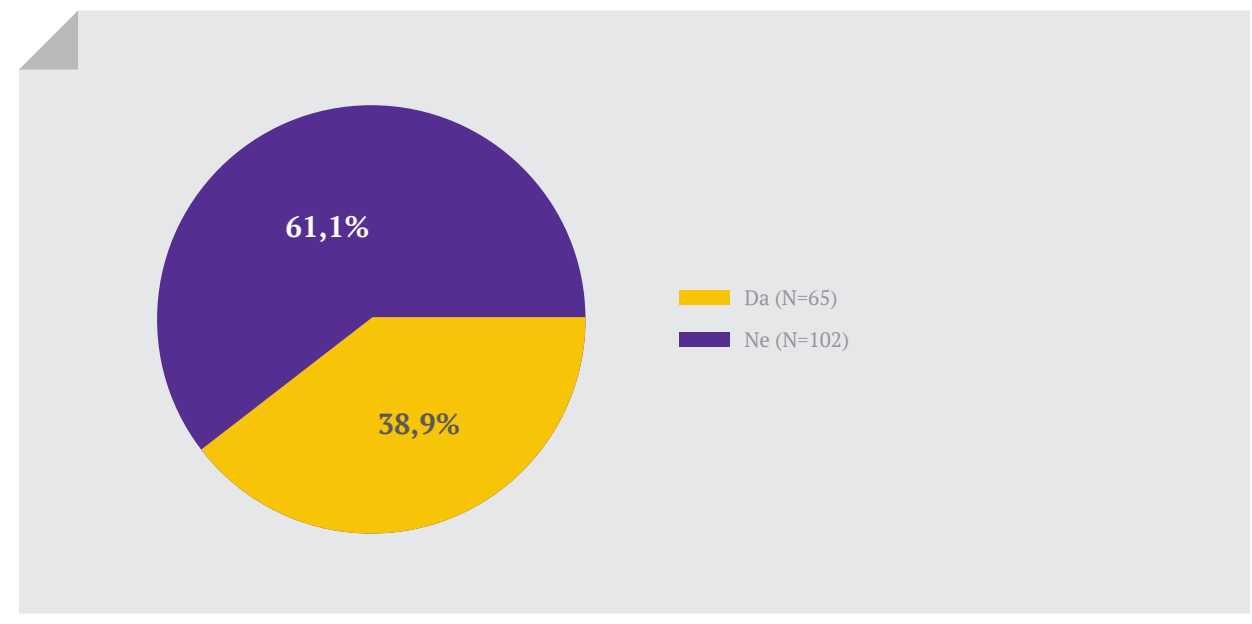

Grafikon 1. Prikaz disperzije odgovora na pitanje „Volite li gledati reality emisije?“ (N=167)

Istraživanja gledanosti reality programa u svijetu pokazuju da su oni veoma popularni među ljudima različitog godišta (Dehnart, 2015). I u ovoj anketi je potvrđen taj trend jer se pokazalo da među ispitanicima različite dobi i spola gledanost iznosi gotovo $40 \%$. 
Što najčešće radite na društvenim mrežama?

Survivor

Big Brother

Masterchef

Hrvatska traži zvijezdu (HTZ)

Skrivena kamera

Shopping kraljica

Tvoje lice zvuči poznato

Keeping up with Kardashians

The Voice

$\mathrm{X}$-factor

Hrvatski Idol

Najslabija karika/Milijunaš/

Potjera

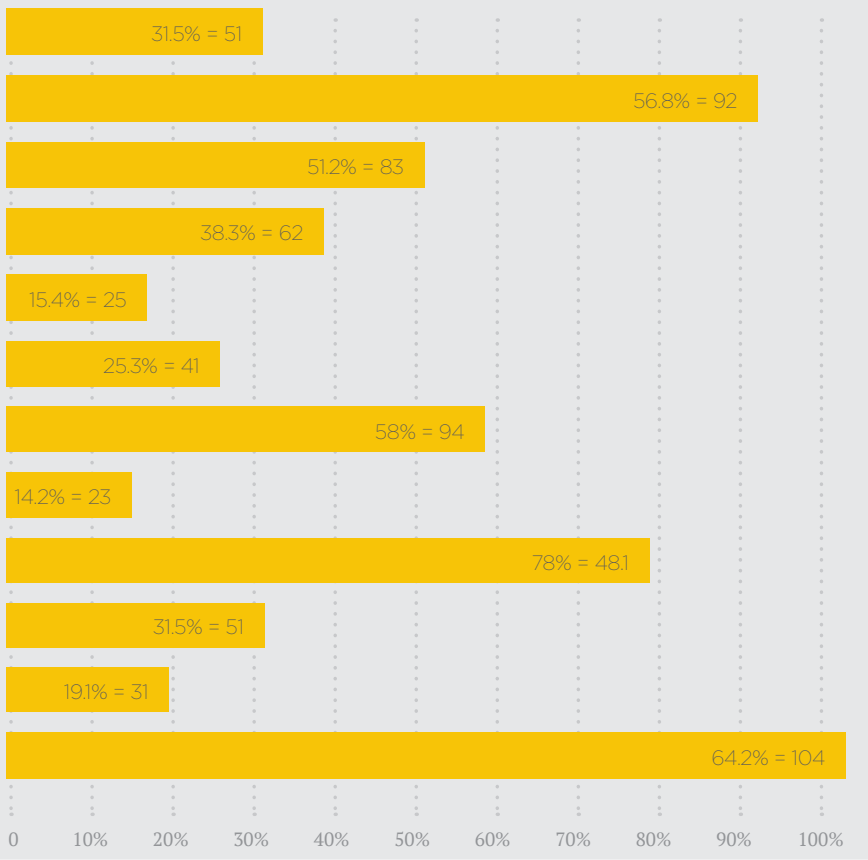

Grafikon 2. Prikaz disperzije odgovora na pitanje „Koje reality emisije ste gledali?“ ( $\mathrm{N}=167)$

Iako postoji veliki broj reality emisija koje se često izmjenjuju na televiziji, u anketi su ponuđene one za koje autorice smatraju da ih je gledalo ili je za njih čuo veći broj ljudi te su različitih provenijencija. Ukupno 102 ispitanika tvrde da ne vole gledati realityje, ali samo ih je petero navelo da nisu gledali niti jednu emisiju. Dakle, 95 \% ispitanih - iako tvrde da ne vole gledati takve sadržaje - gledalo je barem nekoliko takvih emisija. 


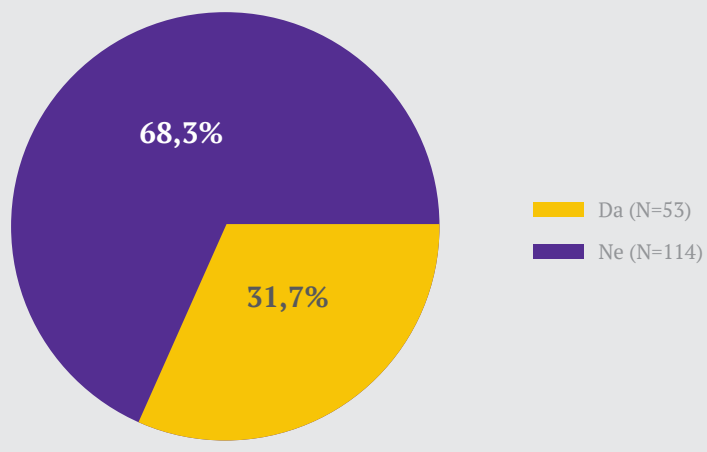

Grafikon 3. Prikaz disperzije odgovora na pitanje „Vraćate li se gledanju nekog realityja iako ste rekli da ga više nećete gledati ?“ (N = 167)

Ovim se pitanjem željela ustanoviti navika gledanja reality programa. Gotovo $32 \%$ ispitanika reklo je da se vraća takvom programu iako to prvotno nisu planirali. Tonči Trstenjak (2006, str. 82) objašnjava da se ovisnost o televiziji manifestira tako da nam se teško odvojiti od nje jer imamo osjećaj da ćemo nešto važno propustiti ili osjećamo veliku prazninu ako je ne gledamo, stoga smo često spremni gledati i besmislice jer je teško ugasiti televiziju.

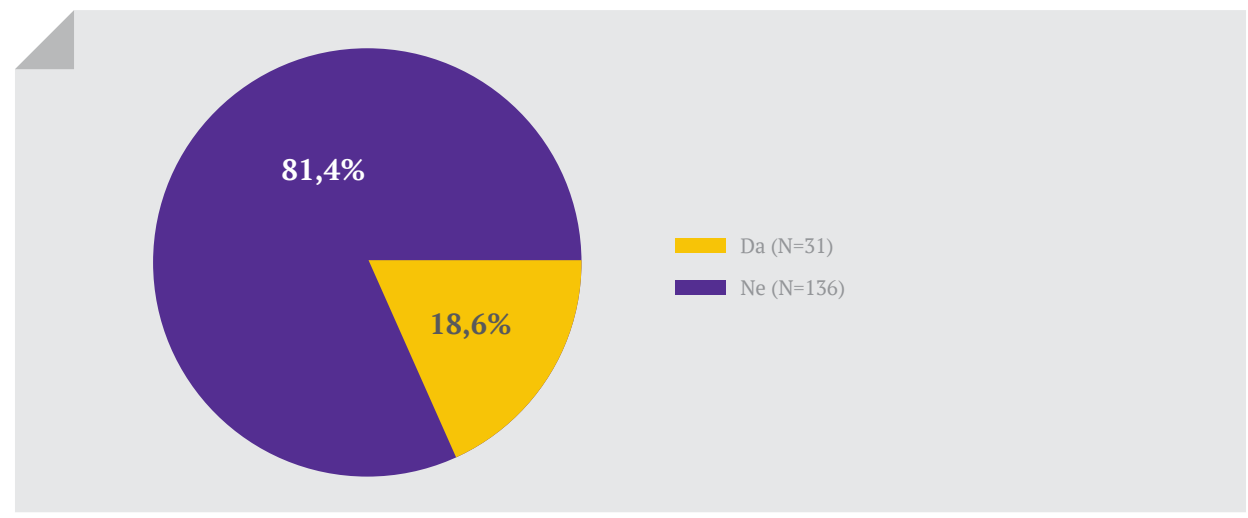

Grafikon 4. Prikaz disperzije odgovora na pitanje „Govorite li ljudima da gledate reality emisije?“(N = 167)

Ovim se pitanjem želi istražiti osjećaju li gledatelji nelagodu priznati drugima da gledaju reality program. Anketa je pokazala da ispitanici nemaju problem priznati da gledaju takav program. 
Inače, od 55 \% Amerikanaca koji gledaju reality, njih 27 \% sebe će nazvati „zagriženim fanom“ koji gledaju što više epizoda i sadržaja vezanih uz najdraže reality programe, a njih 37 \% radije će gledati stvarne ljude na televiziji nego skriptirane scenarije (Gardyn, 2016).

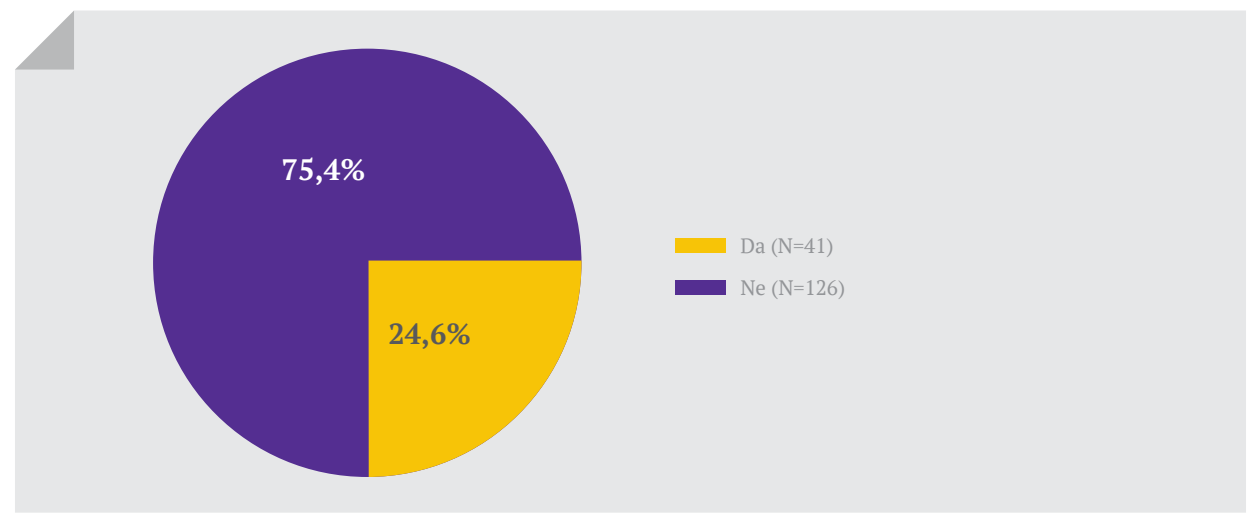

Grafikon 5. Prikaz disperzije odgovora na postavljenu tezu „Počeo/la sam gledati jer ih drugi gledaju te komentiraju pa me zainteresiralo“ $(\mathrm{N}=167)$

Anketa je pokazala kako ljudi sami pokazuju interes za gledanjem. Ipak, reality privlači raznoliku publiku koja kasnije voli komentirati pogledani sadržaj na internetu ili čitati komentare drugih (Gardyn, 2016). Online anketa portala Adage.com (Gardyn, 2016) pokazala je kako 47 \% ispitanika čita članke na internetu vezane uz reality program, 46 \% gleda intervjue s natjecateljima, a $31 \%$ posjećuje internetske stranice vezane uz reality programe.

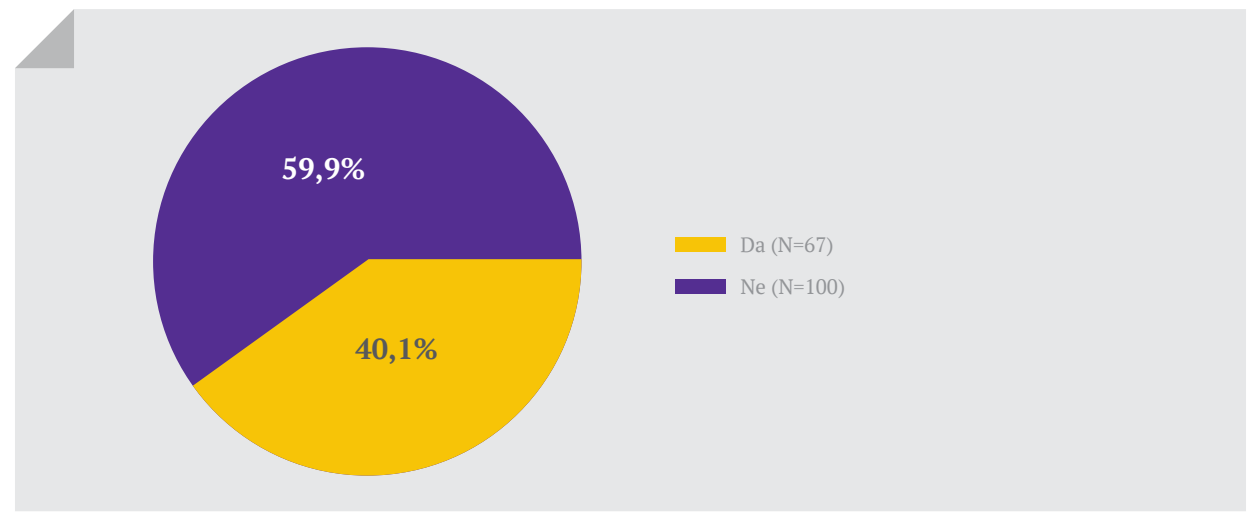

Grafikon 6. Prikaz disperzije odgovora na pitanje „Koliko puta tjedno gledate reality emisije?“ $(\mathrm{N}=167)$ 
Istraživanjem smo analizirale i koliko vjernu publiku ima ova vrsta programa. Anketa pokazuje da ih većina ispitanika ne gleda redovito, odnosno njih $60 \%$, no činjenica da veliki broj televizijskih kuća prikazuje reality emisije, pokazuje da ovaj format uvijek ima svoju vjernu publiku.

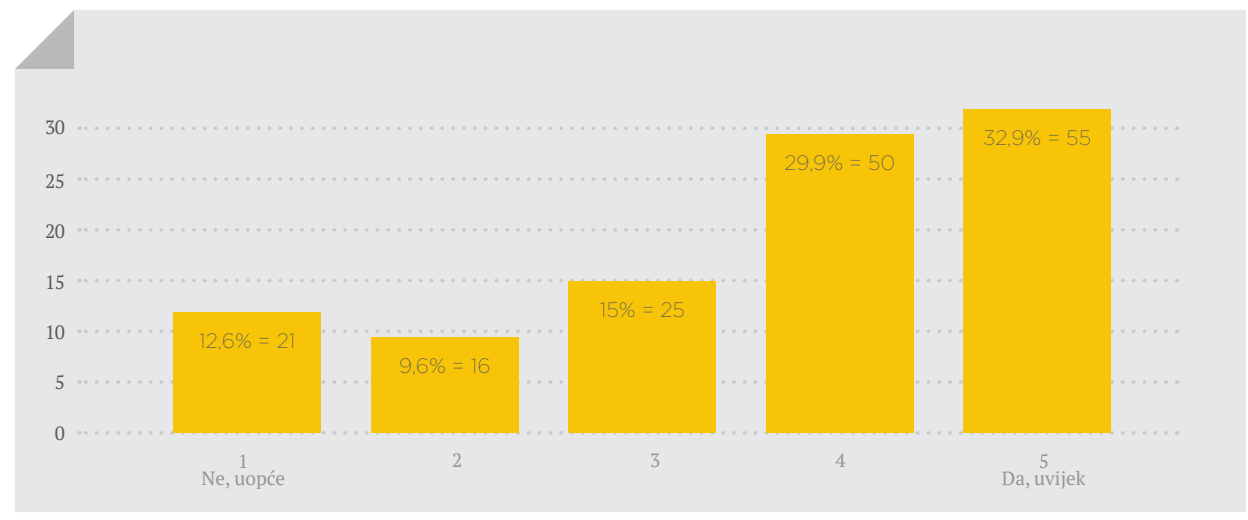

Grafikon 7. Prikaz disperzije odgovora na tezu „Reality emisije možemo promatrati i kao sociološka istraživanja i ponašanja ljudi“ (N = 167)

Zanimljivo je da je više od polovice ispitanika prepoznalo vrijednosti koje sa sociološke strane može imati promatranje skupina ljudi u zatvorenom prostoru. Ranije spomenuti stanfordski zatvorski eksperiment grubi je prikaz toga kako se ljudi ponašaju, ali i dobar pokazatelj kako lako stvari mogu izmaći kontroli.

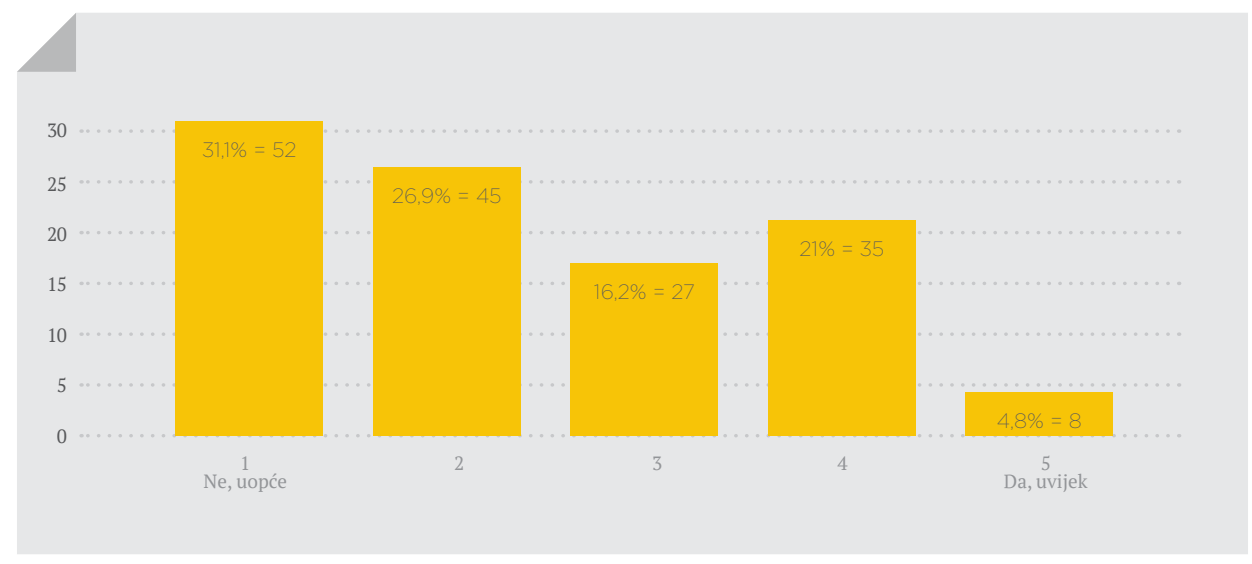

Grafikon 8. Prikaz disperzije odgovora na tezu „Osim zabavne, reality emisije imaju i edukativnu stranu“ $(\mathrm{N}=167)$ 
Primarna funkcija reality programa je zabava i to je nešto što se ni $u$ jednom trenutku ne želi osporavati. No, određeni dio reality programa ima i edukativne elemente poput, primjerice, emisije Zalagaonica (Pawn Shop) u kojoj se na ekranu prikazuju točne informacije i povijesna pozadina predmeta koji se prodaju, odnosno kupuju ili ranije navedenog Survivora. Iz ovog pitanja razvidno je da ispitanici na prvi pogled ne prepoznaju da se iz reality emisija nešto može naučiti.

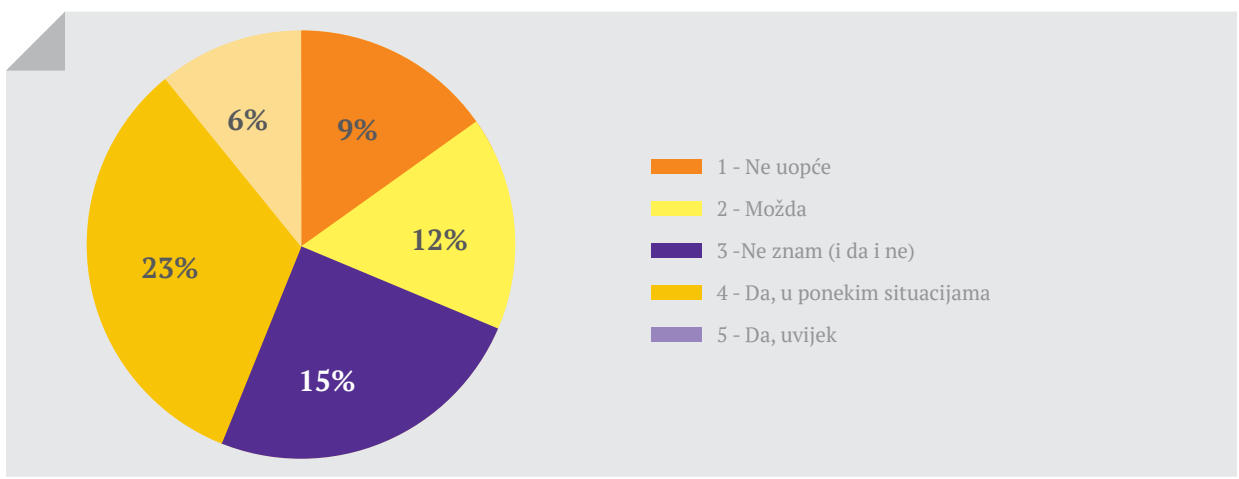

Grafikon 9. Prikaz disperzije odgovora samo onih ispitanika koji vole gledati reality emisije $(\mathrm{N}=167)$

U odgovorima samo onih ispitanika koji su odgovorili da vole gledati realityje, rezultati su drugačiji u odnosu na pitanje iz grafikona br. 8. Odabir „Da, u ponekim situacijama“ dobio je 23 \% odgovora. Nakon njega slijedi „Ne znam (i da i ne)“s 15 \% odgovora.

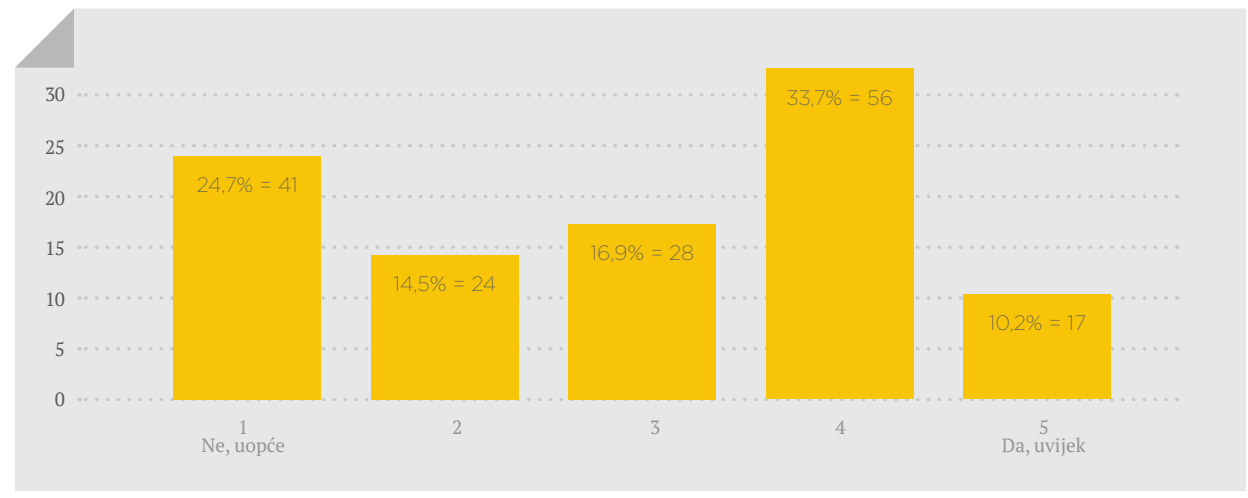

Grafikon 10. Prikaz disperzije odgovora na tezu „Sadržaj koji gledam mi je zanimljiv i zabavan“ (N = 167) 
Glavni razlog gledanja reality programa uvjerljivo je zabava. Kao i kod prethodnog pitanja, ako se izdvoje odgovori ispitanika koji vole gledati reality program, vidljivo je da veći broj ispitanika odgovara s „Da, ponekad“, a najveći dio negativnih odgovora dolazi od ispitanika koji ne vole gledati takve sadržaje. Očekivano, ispitanici kojima je takav program zabavan, oni ga i gledaju, dok ostali ne nalaze ništa zabavno ili zanimljivo u njima.

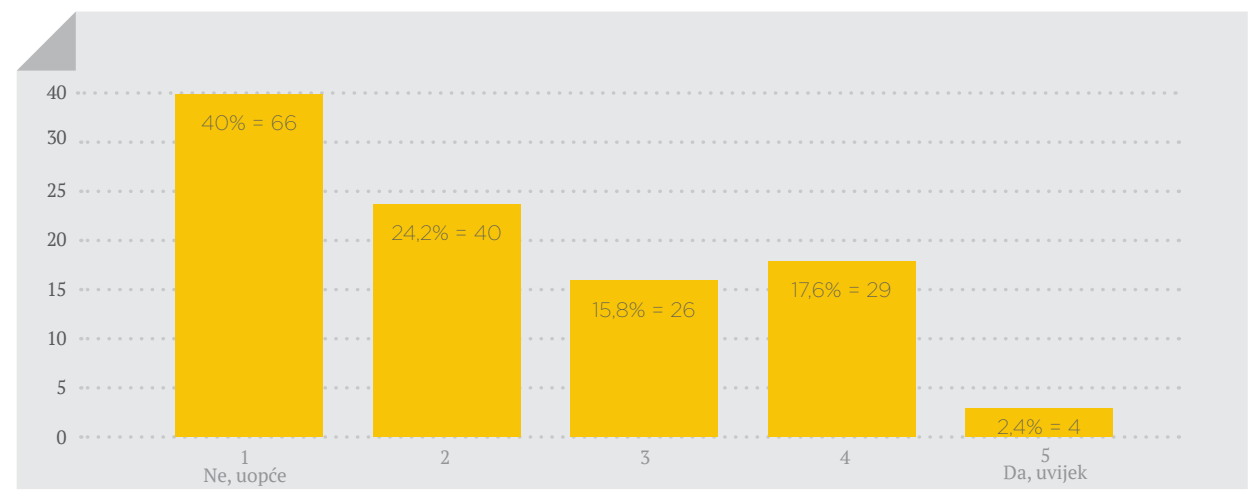

Grafikon 11. Prikaz disperzije odgovora na tezu „Kroz reality sam naučio/la ili saznao/la nešto što inače ne bih imao/la prigodu“ (N = 167)

Sudionici ankete procijenili su da reality programi nemaju informativnu vrijednost i da putem njih ne saznaju nove stvari. Većina reality programa koji se prikazuju na televiziji za njih nema visoko informativnu vrijednost, no to nije isključivo pravilo. Kvizovi provjere znanja ili, primjerice, kulinarska natjecanja nude mnoštvo novih informacija, ali su izgubljeni u velikom broju loših reality programa i ljudi ih kao takve ne prepoznaju.

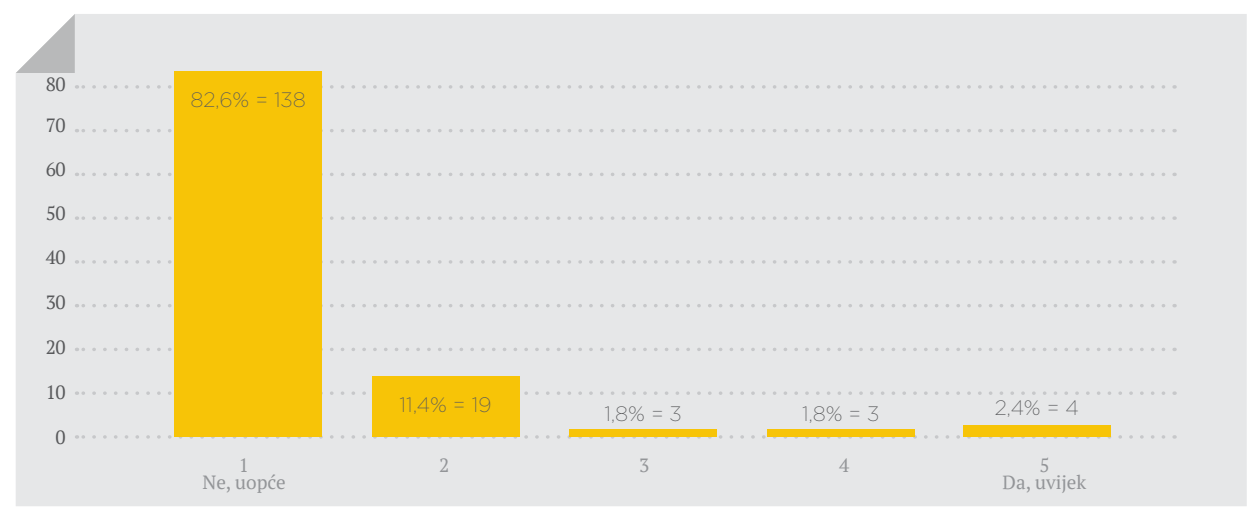

Grafikon 12. Prikaz disperzije odgovora na tezu „I sam/a bih se prijavio/la za sudjelovanje u reality emisijama“ $(\mathrm{N}=167)$ 
Istraživanje je pokazalo da većina ljudi ipak više uživa u gledanju nego u sudjelovanju u reality emisijama. Jo Lamble (prema Bruce, 2016), američka psihologinja zadužena za nadgledanje natjecatelja u reality emisiji temeljenoj na vezama ljudi (Seven Year Switch), kaže kako postoji nekoliko razloga zašto se ljudi prijavljuju na reality emisije. Primjerice, Survivor privlači ljude koji žele sebi dokazati da mogu postići nešto veliko i prihvatiti izazov koji im se nudi, a ne da, primjerice, postanu slavni.

\section{Zalključalk}

Televizija se gleda svakodnevno od „malih nogu“ i izvor je zabave, informacija i obrazovanja. I to je prihvatljivo dok god se kontrolira što i koliko, u kojoj dobi te na koji način gledamo televizijske sadržaje. Međutim, neki od sadržaja kao što je reality televizija - iznimno popularni i gledani te primarno zabavni sadržaj koji je od svojih početaka pod povećalom javnosti - često je i šokantan, sadrži golotinju i psovke, vulgarnosti te neprimjerene elemente, osobito za one najmlađe. Iako se to često ne može primijetiti na prvi pogled, reality u sebi sadrži i korisne informacije.

U svakodnevnom životu često smo izloženi situacijama iz kojih se naizgled ne može ništa naučiti, ali na svakom je pojedincu da iz takvih situacija izvuče nešto korisno. Po sličnom su principu napravljeni i prvi reality socijalni eksperimenti, Broj $28 \mathrm{~s}$ tinejdžerima ili kasnija Ekspedicija na Mars kojom se htjelo provjeriti kako će se skupina ljudi ponašati na malom prostoru kroz duže vremensko razdoblje. Velika raznolikost žanrova reality programa pokazuje da ih se ne može gledati jednostrano kao isključivo zabavu ili isključivo edukaciju jer je to upravo mješavina tih dvaju segmenata. Neki programi svoj sadržaj više temelje na zabavi, kao Survivor ili Skrivena kamera, a drugi kroz zabavu žele educirati gledatelja u kvizovima ili kulinarskim emisijama poput Masterchefa ili Života na vagi.

Preporuke hrvatske Agencije za elektroničke medije namijenjene medijskim djelatnicima, roditeljima i nastavnicima o tomu da reality programi mogu sadržavati štetne sadržaje za djecu i mlade, za one koji ih samo gledaju te za one koji u njima sudjeluju iznimno je vrijedan dokument. Također je i podloga za daljnja istraživanja i proučavanja ovog fenomena jer se takav sadržaj razvija kroz nove žanrove kojima nije isključivi cilj privlačenje publike kroz senzaciju, skandale, stereotipe i predrasude, već se neki protagonisti stavljaju u službu pokazivanja i poticanja na upoznavanje pa i edukaciju o područjima koja su publici zanimljiva, a vrlo često i nedohvatljiva. 


\section{Popis literature}

- Burns, K. S. (2009). Celeb 2.0: How Social Media Foster OurFascinationwith Popular Culture. ABC-CLIO.

- Gardyn, R. (2016). American Demographics. Adage, 23 (9), 34. Dostupno na: http://adage.com/article/american-demographics/tribe-spoken/43086/. Preuzeto 13. prosinca 2018.

- Kronja, I. (2008). Čovjek tranzicije u mas-medijskom društvu (slučaj Srbija). Filozofska istraživanja, 28 (1), 97-106.

- Tkalac Verčič, A., Sinčić Ćorić, D., Pološki Vokić, N. (2010). Priručnik za metodologiju istraživačkog rada: Kako osmisliti, provesti i opisati znanstveno i stručno istraživanje. Zagreb: MEP.

- Trstenjak, T. (2006.) Ovisnost o televiziji. Obnovljeni život: časopis za filozofiju i religijske znanosti, 61 (1), 79-88.

- Vujević, M. (2002). Uvođenje u znanstveni rad. Zagreb: Školska knjiga.

\section{Internetski izvori}

- Agencija za elektroničke medije (2015). Analiza gledanosti. Dostupno na: http://www.e-mediji.hr/hr/analizagledanosti-televizijskog-programa-u-hrvatskoj/gledanost-tv-programa-lipanj-2015/. Preuzeto 24. listopada 2016.

- Agencija za elektroničke medije (2016). Preporuke za zaštitu djece i sigurno korištenje elektroničkih medija. Dostupno na: http://www.medijskapismenost.hr/wp-content/uploads/2016/09/medijska-pismenost-preporuke-dokument. pdf. Preuzeto 10. studenoga 2017.

- Andreeva, N. (2014). Reality Series From Lionsgate TV \& Roy Bank To Chronicle Mission To Colonize Mars. Dostupno na: http://deadline.com/2014/03/mars-colony-reality-series-mars-one-lionsgate-television-698010/. Preuzeto 11. listopada 2016.

- Bruce, C. (2016). What Motivates Us To Go On Reality TV? Psychologist Explains. Dostupno na: https://hope1032. com.au/stories/culture/tv-reviews/2016/reality-tv-motivation-psychologist-explains/. Preuzeto 11. listopada 2016.

- Dehnart, A. (2015) The top 201 reality TV showsandtheirviewers' ages. Dostupno na: https://www.realityblurred. com/realitytv/2015/10/reality-tv-show-viewer-ages/. Preuzeto 11. siječnja 2017.

- EmmyAwards (n.p.). Dostupno na: http://www.emmys.com/shows/oceanquest. Preuzeto 7. siječnja 2017.

- Filipović, M. (2014). Deset godina kasnije: Gdje su zvijezde prvog Big Brothera. Dostupno na: http://www.24sata.hr/ show/deset-godina-kasnije-gdje-su-zvijezde-prvog-big-brothera-391128. Preuzeto 7. siječnja 2017.

- Hobbyfan (2014). Classic TV: The American Sportsman (1965). Dostupno na: http://thelandofwhatever.blogspot. hr/2014/05/classic-tv-american-sportsman-1965.html. Preuzeto 7. siječnja 2017.

- IMBd (1990). Dostupno na: http://www.imdb.com/name/nm0663789/. Preuzeto 7. siječnja 2017.

- La, B. (2015). Odlučeno: Big Brother zbog seksa mora hitno u kasniji termin. Dostupno na: http://www.index.hr/ black/clanak/big-brother-pod-hitno-mora-preseliti-u-drugi-termin/841082.aspx. Preuzeto 10. studenoga 2015.

- Leksikon radija i televizije (2016). Reality televizija. Dostupno na: http://obljetnica.hrt.hr/leksikon/r/reality-televizija/. Preuzeto 10. studenoga 2017.

- Medijska pismenost.hr (2017). Reality emisije i programi za otkrivanje talenata: jesu li štetni za djecu? Dostupno na: http://www.medijskapismenost.hr/reality-emisije-programi-otkrivanje-talenata-jesu-li-stetni-djecu/. Preuzeto 10. studenoga 2017.

- Oxfordski rječnik (2016). Reality TV. Dostupno na: dictionary https://en.oxforddictionaries.com/definition/reality_tv. Preuzeto 24. listopada 2016.

- Peticije24.com (2016). Protiv bluda, nemorala, sunda, kica, zaglupljivanja naroda i propagiranja pogresnih vrednosti!!! Dostupno na: http://www.peticije24.com/srbija_protiv_farme_parova_i_vb. Preuzeto 24. listopada 2016.

- Plečko, D. (2016). Dostupno na: https://www.facebook.com/dragopleckoofficial/posts/880736122034838. Preuzeto 1. studenoga 2016. 
- Reality Television Show (2017). Dostupno na: https://realitytelevisionshow.wordpress.com/about/syllabus/. Preuzeto 7. siječnja 2017.

- Sanderson, B. (1999). Candid Camera Host Allen Funt Dead at Age 84. Dostupno na: http://nypost.com/1999/09/07/ candid-camera-host-allen-funt-dead-at-age-84/. Preuzeto 7. siječnja 2017.

- Stannard, M. B. (2002). BBC's 'reality' show may be cruel and unusual television/. Program based on Stanford Prison Experiment. Dostupno na: http://www.sfgate.com/news/article/BBC-s-reality-show-may-be-cruel-andunusual-2879491.php. Preuzeto 28. listopada 2016.

- The Big Brother Rules (n.p.). Dostupno na: http://bigblagger.co.uk/the-rules-2/. Preuzeto 2. veljače 2017.

- Zimbardo, P. G. (2016). The Stanford Prison Experiment. Dostupno na: http://www.prisonexp.org/. Preuzeto 24. listopada 2016. 


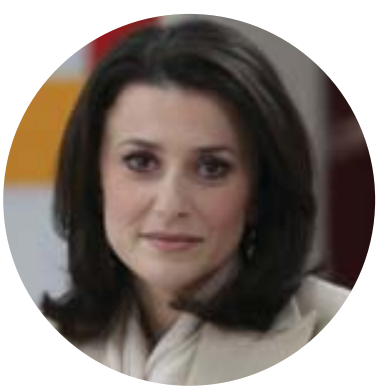

Nensi Blažević

Doktorandica je na Filozofskom fakultetu Sveučilišta u Zagrebu na Odsjeku za informacijske i komunikacijske znanosti. U proteklih gotovo dvadeset godina, radila je za Hrvatsku nacionalnu televiziju - HRT, 24 Hours TV i Al Jazeera Balkans kao novinarka, urednica i voditeljica. Svoj novinarski rad nadogradila je znanstvenom i akademskom aktivnošću. Sudjelovala je na brojnim konferencijama, okruglim stolovima i projektima vezanima uz medijsku pismenost te je autorica nekoliko stručnih i znanstvenih članaka. Kao vanjska suradnica predavala je na Veleučilištu VERN' u Zagrebu, a trenutačno je predavačica je na Fakultetu političkih znanosti Sveučilišta u Zagrebu. Članica je Etičkog vijeća Hrvatske udruge za samoregulativu tržišnih komunikacija.

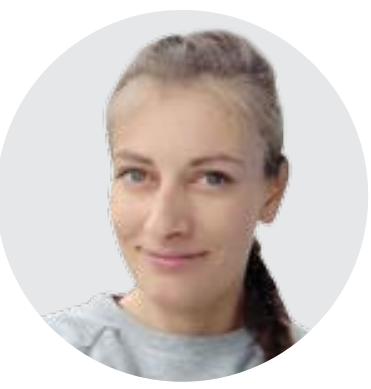

\section{Jana Bušić}

Od 2017. godine prvostupnica je novinarstva Veleučilišta VERN' u Zagrebu. Novinarsko iskustvo stjecala je na jednom news portalu. Glavna preokupacija joj je internetsko novinarstvo, a uz freelance projekte piše te uređuje svoj blog. Radila je i kao dio tima za odnose s javnošću na zagrebačkom INmusic festivalu.

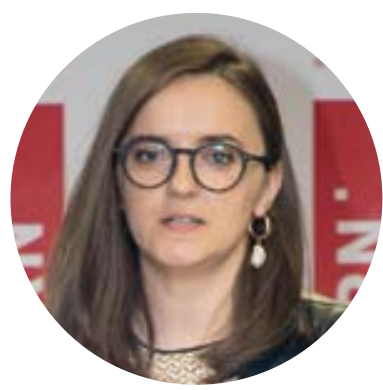

\section{Stana Odak Krasić}

Doktorandica

je

na

poslijediplomskom studiju Jezici $i$ kultura u kontaktu pri Filozofskom fakultetu Sveučilišta u Mostaru. Radi na Veleučilištu VERN' u Zagrebu kao prodekanica za Studije i nastavnica. Kao vanjska suradnica radi ili je radila $\mathrm{i}$ na Visokoj školi međunarodnih odnosa i diplomacije Dag Hammarskjöld, Visokoj poslovnoj školi Zagreb, Visokoj školi za odnose s javnošću i studij medija Kairos te Pučkom učilištu na programu usavršavanja za glasnogovornike. Sudjelovala je na brojnim konferencijama, okruglim stolovima, stručnim skupovima te profesionalnim usavršavanjima od kojih se posebno ističe Program stručnog usavršavanja Aktivno učenje $i$ kritičko mišljenje u visokoškolskoj ustanovi (ALCT program). Aktivna je članica Hrvatske udruge za odnose s javnošću (HUOJ). 